\title{
Deteksi Dini Motorik Kasar pada Anak Usia 4-6 Tahun
}

\author{
Humaedi $^{1}{ }^{\bowtie}$, Andi Saparia ${ }^{2}$, Besse Nirmala $^{3}$, Ikhwan Abduh ${ }^{4}$ \\ Pendidikan Jasmani, Kesehatan, dan Rekreasi, Universitas Tadulako, Indonesia(1,2,4) \\ Pendidikan Guru Pendidikan Anak Usia Dini, Universitas Tadulako, Indonesia(3) \\ DOI: $\underline{10.31004 / o b s e s i . v 6 i 1.1368}$
}

\begin{abstract}
Abstrak
Gerak bagi manusia merupakan kebutuhan terlebih bagi anak yang masih dalam proses tumbuh kembang. Penelitian ini berupaya untuk melakukan deteksi dini motorik kasar anak usia 4-6 Tahun di Kota Palu. Penelusuran yang dilakukan menggunakan penelitian deksriptif. Sampel terdiri dari 344 anak terbagi atas 168 orang anak laki-laki dan 176 anak perempuan yang tersebar di 20 lembaga PAUD yang ada di kota Palu dengan menggunakan teknik total sampling. Teknik pengumpulan data menggunakan 4 jenis tes yakni (1) tes meloncat tanpa awalan, (2) tes berdiri satu kaki, (3) tes kekuatan tangan, dan (4) tes kecepatan. Teknik analisis dengan menggunakan analisis deskriptif persentase. Adapun kesimpulan yaitu hasil pengukuran ditemukan kondisi motorik kasar anak berada pada kategori sedang sehingga dapat dikatakan masih dalam tahap perkembangan. Olehnya itu, hendaknya guru PAUD lebih menekankan model pembelajaran yang memacu kemampuan gerak motorik kasar sehingga dapat mendukung pencapaian prestasi anak di masa depan.
\end{abstract}

Kata Kunci: deteksi dini; motorik kasar; anak usia dini.

\begin{abstract}
Movement for humans is a necessity, especially for children who are still in the process of growing and developing. This study seeks to conduct early detection of gross motor skills in children aged 4-6 years in Palu City. The search was conducted using descriptive research. The sample consisted of 344 children divided into 168 boys and 176 girls spread across 20 PAUD institutions in the city of Palu using total sampling technique. The data collection technique used 4 types of tests, namely (1) a jumping test without a prefix, (2) a one-legged standing test, (3) a hand strength test, and (4) a speed test. The analysis technique uses descriptive percentage analysis. The conclusion is that the results of the measurements found that the gross motor condition of the child was in the moderate category so that it could be said that it was still in the development stage. Therefore, PAUD teachers should put more emphasis on learning models that stimulate gross motor skills so that they can support children's achievement in the future
\end{abstract}

Keywords: early detection; gross motor; ece.

Copyright (c) 2021 Humaedi, Andi Saparia, Besse Nirmala, Ikhwan Abduh

$\triangle$ Corresponding author:

Email Address : hum771@gmail.com (Palu, Sulawesi Tengah)

Received 24 April 2021, Accepted 10 June 2021, Published 16 Juni 2021 


\section{PENDAHULUAN}

Usia dini merupakan pondasi awal dan utama bagi perkembangan anak dalam segala aspek tumbuh kembangnya. Masa anak usia dini, pertumbuhan kognitif dan gerak harus selalu distimulasi dengan baik karena anak belajar mengenai hal baru dan menguasai jenis gerak baru. Aktifitas fisik yang baik akan dapat mempengaruhi keterampilan motorik dan perkembangan kognitif pada anak (Zeng et al., 2017). Kemampuan motorik anak juga dapat memaksimalkannya dampak pada timbulnya rasa percaya diri dan kestabilan emosi pada anak (Farida, 2016). Perkembangan fisik akan memberi dampak secara langsung terhadap keterampilan dan kemampuan anak dalam membentuk variasi gerak. Perkembangan motorik anak akan sangat berperan dalam menunjang kebugaran anak karena dengan melakukan gerak intens di kehidupan sehari-hari secara tidak langsung akan melatih fisik untuk menjadi lebih bugar (Sepriadi, 2017).

Motorik kasar yang berkembang secara baik memberi banyak manfaat yakni memberi kemampuan kepada anak untuk dapat menguasai gerakan yang tergolong dalam gerakan yang sulit dilakukan oleh orang. Selain itu, memberi kemampuan fisik yang lebih mumpuni seperti tidak mudah lelah dalam melakukan aktifitas (Frith \& Loprinzi, 2019), baik dalam aktifitas fisik dalam bertanding maupun latihan pada olahragawan. Penguasaan gerak motorik kasar bagi anak terlebih anak usia dini sangat mutlak untuk dilakukan karena akan menjadi pondasi dalam pencapaian prestasi dimasa mendatang. Beberapa studi yang telah melakukan penelusuran mengenai kemampuan motorik misalnya (Saripudin, 2019) yang menganalisis tentang pertumbuhan dan perkembangan anak yang dilihat dari sisi gerak motorik kasar anak hasil studi menemukan bahwa perubahan motorik dapat terjadi pada perubahan ukuran tubuh, proporsi pada tubuh berubahnya ciri fisik lama maupun baru sebagai indikator kematangan suatu organ dalam tubuh.

Studi berikutnya adalah (Wang, 2009) yang melakukan penelusuran terhadap pengaruh gerakan kreatif anak terhadap pola perkembangan keterampilan motorik kasar anak, hasil penelitian terlihat bahwa anak yang tergabung dalam program yang dibuat yakni gerakan kreatif secara signifikan memiliki kemampuan motorik kasar yang lebih baik. Berdasarkan kedua jenis penelitian tersebut terdapat perbedaan dengan studi atau penelitian yang dilakukan, perbedaan tersebut terlihat yaitu penelitian yang telah dilakukan melihat kemampuan motorik kasar anak PAUD di Kota Palu dengan empat indikator ukur yaitu kemampuan motorik daya ledak tungkai, keseimbangan, kekuatan tangan dan kecepatan.

Deteksi dini kemampuan motorik anak pada masa usia dini akan dapat lebih menguntungkan karena dapat langsung memberi treatment apabila ada keganjilan dalam perkembangan gerak motoriknya. Kemampuan motorik juga sangat berhubungan erat dengan kemampuan belajar bagi anak disabilitas (Westendorp et al., 2011). Selain itu, kemampuan anak dalam melakukan gerak motorik kasar merupakan komponen dasar yang dapat memberi dukungan dalam pengembangan aktifitas fisik lainnya (Stodden et al., 2008) sehingga memang sangat penting melakukan deteksi dini tentang kemampuan motorik kasar pada anak usia dini. Penelitian ini dilakukan untuk melakukan deteksi tentang potensi kemampuan motorik kasar pada anak usia pra sekolah atau anak usia dini di Kota Palu Provinsi Sulawesi Tengah.

\section{METODOLOGI}

Penelitian yang dilakukan termasuk dalam penelitian deskriptif kuantitatif yang akan mendeteksi secara dini gerak motorik kasar pada anak di lembaga PAUD Kota Palu. Desain penelitian yang digunakan adalah desain penelitian deskriptif yang hanya menggambarkan secara umum sehingga hanya bersifat asosiatif simetris pada variable dan indikator yang teliti sehingga tidak melihat pola pengaruh antar keduanya (Hermawan, 2019). Desain penelitian dideskripsikan pada bagan 1 . 


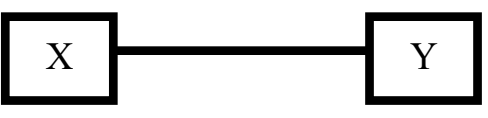

Bagan 1. Desain penelitian

Keterangan

$X=$ Kemampuan Motorik kasar anak

$\mathrm{Y}=$ Indikator ukur (Keseimbangan, Daya Ledak Tungkai, Kekuatan Tangan, Kecepatan)

Tempat penelitian dilakukan di lembaga TK yang tersebar di masing-masing tempat yakni Kecamatan Ulujadi, Palu Selatan, Palu Barat, dan Mantikulore. Setiap Kecamatan di ambil lima lembaga TK sehingga jumlah lembaga yang menjadi tempat penelitian sebanyak 20 lembaga yaitu TK IT Pelita Hati, TK Al-Khairaat Pusat Palu, TK Pembina Kota Palu, TK Pembina Palu Utara, TK Adhiyaksa, TK Madani, TK Aisyiyah I, TK Khalifah, TK Aisyiyah II, TK Al-Khairaat Mamboro, TK Permata Bunda, TK Pelangi, TK Asih, TK Permata Bangsa, TK Kartika, TK Bhayangkari 01, TK Bhayangkari 02, TK Al-Khairaat Tatura, TK Bina Anak Bangsa, dan TK Widyatama. Penelitian ini dilaksanakan pada bulan Mei-September 2020. Jumlah sampel dalam penelitian ini sebanyak 344 anak TK yang berusia 4-6 tahun. Adapun kriteria sampel yang diambil yaitu: sehat dan tidak cacat secara fisik. Responden yang terpilih akan mengikuti serangkaian kegiatan yang dilakukan pada penelitian dari awal sampai akhir secara konsisten. Teknik sampling dilakukan dengan mengambil keseluruhan jumlah anak usia dini yang terdaftar pada sekolah PAUD di Kota Palu (total sampling) sebanyak 344 anak PAUD dengan rincian 168 sampel laki-laki dan 176 perempuan (Arifin, 2020). Alasan menggunakan teknik total sampling agar semua anak di lembaga TK yang menjadi subjek penelitian dapat berpartisipasi sehingga tidak ada perbedaan perlakuan yang diperoleh dari gurunya.

Teknik pengumpulan data menggunakan empat jenis tes yakni: (1) tes meloncat tanpa awalan dilakukan untuk mendeteksi kemampuan daya ledak tungkai anak yang diukur dengan satuan centimeter $(\mathrm{cm}),(2)$ tes berdiri satu kaki untuk melihat kemampuan dalam mempertahankan keseimbangan tubuh yang diukur dengan melihat lama berdiri dengan satu kaki (detik), (3) tes melempar menggunakan bola untuk mendeteksi kekuatan tangan anak usia dini yng diukur dengan satuan (meter), dan (4) tes lari untuk melihat kecepatan anak dengan menggunakan stopwatch yang diukur dengan satuan detik. Instrumen tes ini sebelumnya sudah diuji validitas dan reliabilitasnya oleh para ahli di bidangnya. Kemudian instrumen tes ini terlebih dahulu diujicobakan pada sampel terbatas sebelum diujicoba pada sampel yang sebenarnya. Hasilnya yaitu instrumen ini dinyatakan valid, reliabel dan layak untuk digunakan. Teknik analisis data menggunakan teknik analisis deskriptif persentase selain itu menggunakan rumus penilaian acuan norma yang diadopsi dari (Azwar, 2012) dengan menggunakan 5 kategori yaitu: kurang sekali (skor 1), Kurang (skor 2), Sedang (skor 3), Baik (skor 4), dan Baik Sekali (skor 5).

\section{HASIL DAN PEMBAHASAN}

Penelitian dilakukan dengan melihat potensi kemampuan motorik kasar anak dari empat komponen ukur diantaranya keseimbangan, daya ledak tungkai, kekuatan, kecepatan. Adapun deskriptif potensi kemampuan motorik kasar anak (tabel 1).

Hasil analisis menunjukkan dari segi umur sampel laki-laki dan perempuan rata-rata memiliki umur pada 5 tahun dengan jumlah sampel perempuan sebanyak 176 sedangkan lakilaki 168. Secara fisiologis memang terlihat potensi motorik sampel dengan jenis kelamin lakilaki lebih dominan dibandingkan sampel yang berjenis kelamin perempuan hal tersebut terbukti pada setiap komponen tes sampel laki-laki memiliki skor yang lebih baik dibandingkan sampel perempuan pada komponen motorik yang paling berbeda terlihat pada motorik kasar kekuatan tangan, skor rata-rata sampel laki-laki sebesar 6.2520 sedangkan perempuan hanya 4.5445 namun pada komponen motorik yang lain tidak berbeda jauh. Hasil tersebut selaras dengan studi yang dilakukan oleh (Sgro et al., 2017) hasil studi menunjukkan 
DOI: $10.31004 /$ obsesi.v6i1.1368

tingkat kemahiran dalam motorik anak dengan jenis kelamin pria lebih dominan dibandingkan dengan anak yang berjenis kelamin wanita. Selain itu, studi di Jepang yang menggunakan instrumen pengukuran Test of Gross Motor Development (TGMD-2) menemukan hal berbeda bahwa anak yang berjenis kelamin perempuan lebih baik dalam hal penguasaan gerak lokomotor dibandingkan laki-laki namun memiliki kemampuan motorik kasar yang sama antar kedua jenis kelamin (Aye et al., 2018). Adanya perbedaan tersebut memungkinkan terjadi karena ada perbedaan struktur fisiologis dan intensitas aktifitas fisik. Aktifitas fisik akan berpengaruh terhadap perkembangan gerak terlebih usia yang lebih muda (Burns et al., 2017).

Tabel 1 Deskriptif Potensi Motorik Kasar Anak Usia Dini n= 344

\begin{tabular}{lccccc}
\hline Komponen Ukur & N & $\begin{array}{c}\text { Skor } \\
\text { Minimal }\end{array}$ & $\begin{array}{c}\text { Skor } \\
\text { Maksimal }\end{array}$ & Rerata & SD \\
\hline Umur & 168 & 4 & 6 & 5.71 & 0.538 \\
Laki-laki & 176 & 4 & 6 & 5.68 & 0.548 \\
Perempuan & & & & & \\
Motorik laki-laki & 168 & 1 & 193 & 35.20 & 32.635 \\
Keseimbangan (detik) & 168 & 30 & 163 & 94.89 & 24.566 \\
Daya Ledak Tungkai(cm) & 168 & 1.00 & 14.37 & 6.2520 & 2.39884 \\
Kekuatan Tangan(m) & 168 & 4.02 & 10.03 & 6.5789 & 1.20626 \\
Kecepatan (detik) & & & & & \\
Motorik Perempuan & 176 & 1.05 & 93.23 & 23.8601 & 20.26060 \\
Keseimbangan (detik) & 176 & 13.00 & 160.00 & 85.6193 & 24.11443 \\
Daya Ledak Tungkai(cm) & 176 & 1.20 & 9.40 & 4.5445 & 1.62084 \\
Kekuatan Tangan (m) & 176 & 4.23 & 12.76 & 7.2698 & 1.54894 \\
Kecepatan (detik) & & & & & \\
\hline
\end{tabular}

$\mathrm{SD}=$ Standar Deviasi, N=jumlah sampel

Potensi kemampuan motorik kasar anak pada penelitian ini diukur berdasarkan empat komponen yang dikategorikan kedalam lima skala yaitu: tes meloncat tanpa awalan, tes berdiri satu kaki, tes melempar menggunakan bola, dan tes lari. Berikut pengkategorian kemampuan motorik kasar anak pra sekolah di Kota Palu (gambar 1)

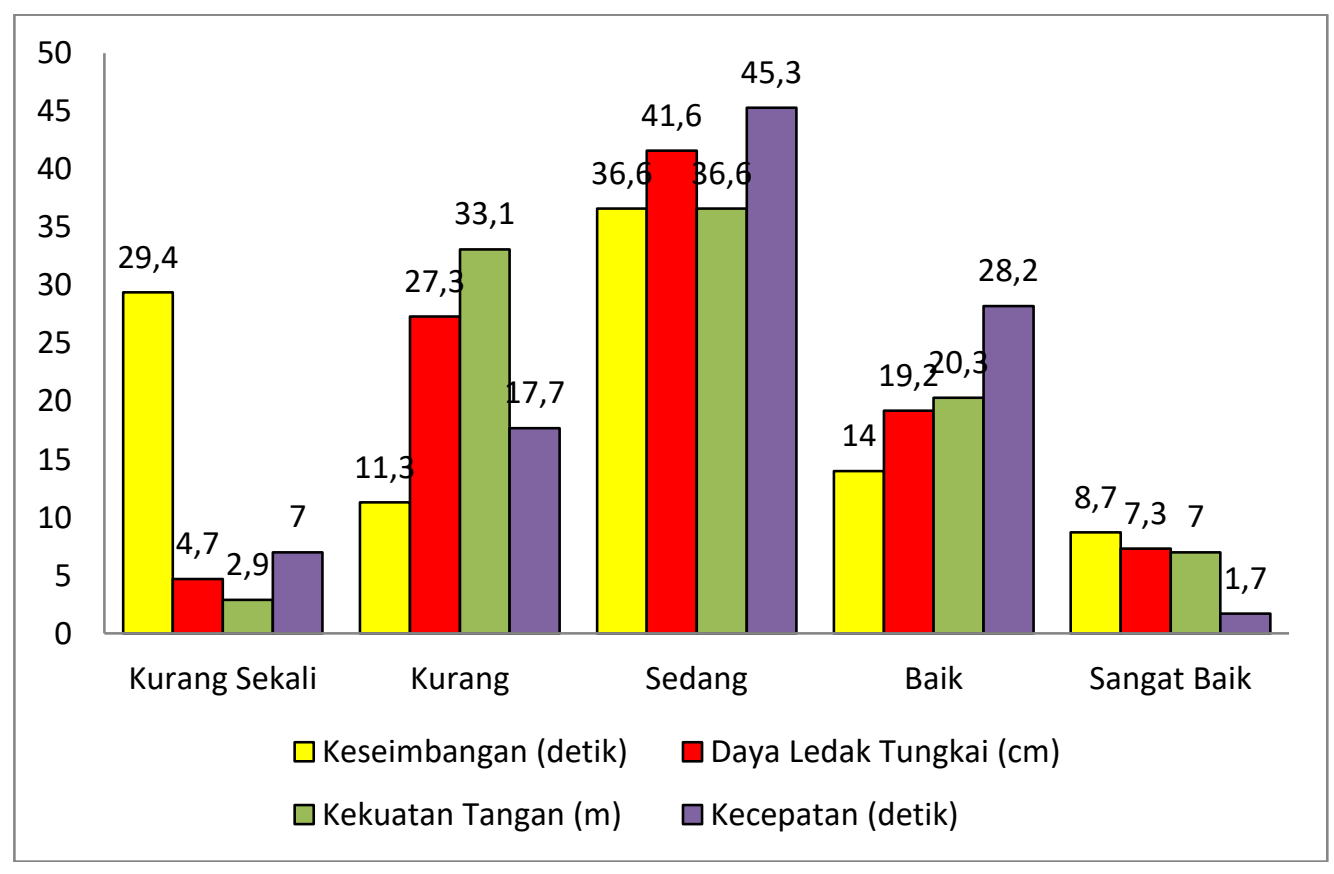

Diagram 1 Pengkategorian Kemampuan Motorik Kasar Anak Usia Dini 
Hasil analisis pada keseluruhan jumlah sampel baik sampel laki-laki maupun perempuan sebanyak 344 komponen motorik kasar keseimbangan paling banyak pada kategori sangat baik yaitu 8,7\% dari keseluruhan jumlah sampel dan berbanding terbalik dengan motorik kasar kecepatan yang hanya 1,7\% anak yang masuk dalam kategori sangat baik. Komponen kecepatan terlihat sangat dominan pada kategori sedang sebanyak 45,3\% dari keseluruhan jumlah sampel. Pada kategori kurang sekali komponen motorik kasar keseimbangan sangat menonjol yakni sebanyak 29,4\%. Berdasarkan diagram di atas, dapat dilihat grafik secara umum pada setiap komponen motorik kasar anak yang diukur masuk pada kategori sedang.

Pada anak usia dini ada banyak faktor yang berpengaruh pada perkembangan motorik kasar anak, misalnya status gizi dan lingkungan (Meylia et al., 2020; Rhomadona, 2020). Sebagai contoh, apabila anak melihat mainan di sekitarnya kecenderungan untuk bergerak akan lebih intens dan mengupayakan potensi motorik yang dimilikinya(Lisa et al., 2020). Selain itu, perbedaan kemampuan gerak anak usia dini dapat dipengaruhi oleh jenis kelamin dan wilayah geografis anak (Goodway et al., 2010). Hasil penelitian yang ditemukan bahwa secara umum kondisi motorik kasar anak usia dini di Kota Palu berada pada kategori sedang sehingga dapat dikatakan masih dalam tahap perkembangan, hasil tersebut memang sesuai dengan proses tumbuh kembang anak pada anak usia dini telah mulai dapat melempar dengan baik, berdiri dengan satu kaki, dan melompat dengan ketinggian tertentu (Saripudin, 2019).

Hal ini juga sesuai dengan pendapat dari Holloway bahwa kemampuan motorik kasar pada anak memiliki peran yang sangat sentral karena juga akan sangat berperan dalam pola hubungan sosial anak terlebih pada anak yang berkebutuhan khusus misalnya authis (Holloway et al., 2018). Pada diagram 1 juga terlihat bahwa kemampuan anak dalam hal keseimbangan paling banyak yang berkategori kurang sekali padahal keseimbangan merupakan potensi fisik yang cukup signifikan dalam menunjang gerak anak. Kurangnya kemampuan dalam hal keseimbangan dapat dipengaruhi oleh banyak factor salah satunya factor frekuensi aktifitas fisik yang dilakukan oleh anak (Pujianto, 2018). Kemampuan keseimbangan pada anak usia dini dapat ditingkatkan dengan aktivitas fisik berbasis kinestetik, selain dapat meningkatkan kemampuan keseimbangan pada anak aktifitas fisik berbasis kinestetik dan kontenporer secara umum dapat meningkatkan motoric kasar anak usia dini (Sutapa \& Suharjana, 2019).

Melihat pentingnya gerak motoric kasar bagi anak usia dini hendaknya menjadi perhatian bagi guru pendidikan anak usia dini (PAUD) disetiap sekolah dengan memacu potensi motoric kasar anak dengan berbagai pendekatan dan metode pembelajaran misalnya dengan memanfaatkan permainan outbound, permainan tradisional (engklek) dan bahkan melalui media permainan hulahoop (Novitasari et al., 2019; Ramdani \& Azizah, 2019; Wiranti \& Mawarti, 2018).

Implikasi dari hasil penelitian ini adalah memberi gambaran bagi guru pendidikan anak usia dini (PAUD) di Kota Palu bahwa motoric kasar anak secara umum hanya masuk pada kategori sedang sehingga dapat menjadi titik tolak dalam penyusunan rencana pembelajaran yang tidak mengindahkan pentingnya motoric kasar anak usia dini, dari hasil penelitian juga dapat menjadi dasar guru untuk secara berkala melakukan pengukuran kemampuan motoric kasar anak untuk mengetahui treatmen lanjutan apabila ditemukan kelainan dalam hasil yang ditemukan. Selain itu, secara teknis penelitian yang dilakukan memang masih memiliki keterbatasan data yang ditemukan dari instrumen yang digunakan sehingga membutuhkan penyempurnaan misalnya dengan menggunakan instrumen Test of Gross Motor Development (TGMD-2) yang lebih detail dalam mengukur kemampuan motorik anak usia dini, sehingga kedepan membutuhkan penelitian lanjutan berdasarkan data awal yang menjadi temuan pada penelitian yang telah dilakukan. 


\section{SIMPULAN}

Hasil penelitian secara umum menunjukkan kemampuan motorik kasar yang terdaftar dalam sekolah PAUD di Kota Palu memiliki kemampuan motorik kasar yang kategori sedang yang terlihat dari empat indikator ukur yang dilakukan paling banyak pada kategori sedang. Berdasarkan hasil penelitian tersebut hendaknya guru pendidikan anak usia dini di Kota Palu lebih menekankan model pembelajaran yang dapat memacu berkembanganya gerak motorik kasar pada anak sehingga dapat mendukung pencapaian prestasi anak didik dimasa depan.

\section{UCAPAN TERIMAKASIH}

Pertama, penulis memanjatkan puji syukur atas kehadirat Allah SWT atas rahmat dan karunia-Nya sehingga penulis dapat menyelesaikan artikel ini. Penulis mengucapkan terima kasih yang sebesar-besarnya kepada seluruh pihak yang terlibat selama proses penelitian dan penyusunan artikel ini. Terima kasih kepada kepala TK dan guru-guru PAUD yang ada di Kota Palu, tim peneliti, observer, dan mahasiswa PG PAUD Universitas Tadulako yang telah membantu peneliti dalam mengumpulkan data. Terakhir penulis juga sampaikan kepada pengelola dan tim reviewer Jurnal Obsesi yang telah memberikan kesempatan sehingga artikel ini dapat dipublikasikan.

\section{DAFTAR PUSTAKA}

Arifin, Z. (2020). Metodologi Penelitian Pendidikan. Jurnal Al-Hikmah, 1(1). http://alhikmah.stit-alhikmahwk.ac.id/index.php/awk/article/view/16

Aye, T., Kuramoto-Ahuja, T., Sato, T., Sadakiyo, K., Watanabe, M., \& Maruyama, H. (2018). Gross motor skill development of kindergarten children in Japan. Journal of Physical Therapy Science, 30(5), 711-715. https:// doi.org/10.1589/jpts.30.711

Azwar, S. (2012). Reliabilitas dan Validitas (4th ed.). Pustaka Belajar.

Burns, R. D., Fu, Y., Fang, Y., Hannon, J. C., \& Brusseau, T. A. (2017). Effect of a 12-Week Physical Activity Program on Gross Motor Skills in Children. Perceptual and Motor Skills, 124(6), 1121-1133. https:// doi.org/10.1177/0031512517720566

Farida, A. (2016). Urgensi Perkembangan Motorik Kasar Pada Perkembangan Anak Usia Dini. Jurnal Raudhah, 4(2), 1-10. http://dx.doi.org/10.30829/ raudhah.v4i2.52

Frith, E., \& Loprinzi, P. D. (2019). Association Between Motor Skills and Musculoskeletal Physical Fitness Among Preschoolers. Maternal and Child Health Journal, 23(8), 10031007. https:// doi.org/10.1007/s10995-019-02753-0

Goodway, J. D., Robinson, L. E., \& Crowe, H. (2010). Gender Differences in Fundamental Motor Skill Development in Disadvantaged Preschoolers From Two Geographical Regions. Research Quarterly for Exercise and Sport, 81(1), 17-24. https://doi.org/10.1080/02701367.2010.10599624

Hermawan, I. (2019). Metodologi Penelitian Pendidikan, Kuantitatif, Kualitatif, dan Mixed Methode. Hidayatul Quran Kuningan.

Holloway, J. M., Long, T. M., \& Biasini, F. (2018). Relationships Between Gross Motor Skills and Social Function in Young Boys With Autism Spectrum Disorder. Pediatric Physical Therapy, 30(3), 184-190. https://doi.org/10.1097/PEP.0000000000000505

Lisa, M., Mustika, A., \& Lathifah, N. S. (2020). Alat Permainan Edukasi (APE) Meningkatkan Perkembangan Motorik Halus pada Anak Usia 4-6 Tahun. Jurnal Kesehatan, 11(1), 125. https:// doi.org/10.26630/jk.v11i1.1584

Meylia, K. N., Siswati, T., Paramashanti, B. A., \& Hati, F. S. (2020). Fine motor, gross motor, and social independence skills among stunted and non-stunted children. Early Child Development and Care, 1-8. https:// doi.org/10.1080/03004430.2020.1739028

Novitasari, R., Nasirun, M., \& D., D. (2019). Meningkatkan Kemampuan Motorik Kasar Anak Melalui Bermain Dengan Media Hulahoop Pada Anak Kelompok B Paud Al-Syafaqoh Kabupaten Rejang Lebong. Jurnal Ilmiah POTENSIA, 4(1), 6-12. https://doi.org/10.33369/jip.4.1.6-12 
Pujianto, D. (2018). Physical Activity and Static Balance on Early Childhood. Journal of Physical Education, Sport, Health and Recreations, 7(2), 68-72. https:// doi.org/10.15294/active.v7i2.22419

Ramdani, L. A., \& Azizah, N. (2019). Permainan Outbound untuk Perkembangan Motorik Kasar Anak Usia Dini. Jurnal Obsesi : Jurnal Pendidikan Anak Usia Dini, 4(1), 494. https://doi.org/10.31004/obsesi.v4i1.407

Rhomadona, S. W. (2020). Gambaran Faktor-Faktor Yang Mempengaruhi Perkembangan Motorik Pada Balita Usia 4-5 Tahun Di Tk Siswa Harapan, Ciliwung-Surabaya. Jurnal Kebidanan, 9(1), 1-9. https:// doi.org/10.47560/keb.v9i1.235

Saripudin, A. (2019). Analisis Tumbuh Kembang Anak Ditinjau Dari Aspek Perkembangan Motorik Kasar Anak Usia Dini. Equalita: Jurnal Pusat Studi Gender Dan Anak, 1(1), 114. https://doi.org/10.24235/equalita.v1i1.5161

Sepriadi, S. (2017). Kontribusi Status Gizi dan Kemampuan Motorik Terhadap Kesegaran Jasmani Siswa Sekolah Dasar. Jurnal Keolahragaan, 5(2), 194. https:// doi.org/10.21831/jk.v5i2.15147

Sgro, F., Quinto, A., Messana, L., Pignato, S., \& Lipoma, M. (2017). Assessment of Gross Motor Developmental Level in Italian Primary School Children. Journal of Physical Education and Sport, 17(03), 1954-1959.

Stodden, D. F., Goodway, J. D., Langendorfer, S. J., Roberton, M. A., Rudisill, M. E., Garcia, C., \& Garcia, L. E. (2008). A Developmental Perspective on the Role of Motor Skill Competence in Physical Activity: An Emergent Relationship. Quest, 60(2), 290-306. https:// doi.org/10.1080/00336297.2008.10483582

Sutapa, P., \& Suharjana, S. (2019). Improving Gross Motor Skills by Gross Kinesthetic-and Contemporary-Based Physical Activity in Early Childhood. Jurnal Cakrawala Pendidikan, 38(3), 540-551. https:// doi.org/10.21831/cp.v38i3.25324

Wang, J. H.-T. (2009). A Study on Gross Motor Skills of Preschool Children. Journal of Research in Childhood Education, 19(1), 32-43. https:// doi.org/10.1080/02568540409595052

Westendorp, M., Hartman, E., Houwen, S., Smith, J., \& Visscher, C. (2011). The relationship between gross motor skills and academic achievement in children with learning disabilities. Research in Developmental Disabilities, 32(6), 2773-2779. https://doi.org/10.1016/j.ridd.2011.05.032

Wiranti, D. A., \& Mawarti, D. A. (2018). Keefektiffan Permainan Engklek Dalam Mengembangkan Kemampuan Motorik Kasar Anak Usia Dini. Refleksi Edukatika : Jurnal Ilmiah Kependidikan, 9(1). https:/ / doi.org/10.24176/re.v9i1.2810

Zeng, N., Ayyub, M., Sun, H., Wen, X., Xiang, P., \& Gao, Z. (2017). Effects of Physical Activity on Motor Skills and Cognitive Development in Early Childhood: A Systematic Review. BioMed Research International, 2017, 1-13. https://doi.org/10.1155/2017/2760716 